\title{
1 Introduction and overview to current issues in antitrust economics
}

Einer Elhauge

Although economic analysis of law is increasingly important in many legal fields, perhaps no field of law is as dominated by economics as antitrust law. This no doubt reflects a confluence of factors. First, serious economic analysis of law really began with antitrust law, so economic analysis into antitrust issues has had time to go deeper and wider than economic analysis of other legal fields. Second, so much of standard microeconomics is directly relevant, given that antitrust involves regulating market competition. Third, the courts and enforcement agencies have grounded antitrust legal doctrines explicitly in concepts of antitrust economics. Fourth, because of the last factor, antitrust law creates a series of issues on which expert testimony on antitrust economics is relevant, meaning that every antitrust case of significance has at least one (often more) testifying expert on antitrust economics on each side. Antitrust law is thus unusual not only in the extent to which it turns on economics, but also in the extent to which that economics is vigorously debated in each case.

One might mistakenly think that such a long tradition would mean that there would be little new to say about antitrust economics. Yet antitrust economics is surprisingly dynamic and changing. In part, this is because new decisions or legal developments, often in response to old economic developments, tend to raise new economic issues. In part, it is because the continued testing of economic logic in adversarial economic testimony leads to continued self-reflection.

Given the rich literature in antitrust economics, this handbook does not purport to provide an exhaustive overview of all it has to tell us. This handbook focuses on those areas of antitrust economics that are most in flux because of new developments in law or the economics literature.

\section{PART I MERGERS AND MARKET DEFINITION}

Perhaps one of the most important recent developments is the promulgation of the 2010 US Horizontal Merger Guidelines. The new guidelines are notable in their increased emphasis on unilateral effects theory, their de-emphasis of market definition, and their inclusion of mergers that eliminate potential competition (which were previously classified as non-horizontal). Part I of this handbook includes a chapter on each of these three developments, illuminating the relevant economic issues.

Chapter 2 - Unilateral Effects Under Modern Merger Analysis. A merger is said to have unilateral effects when it reduces the incentives of the merged firm to compete aggressively, holding constant the strategies of non-merging rivals. Jon Baker and David Reitman's chapter provides a timely assessment of how mergers can produce adverse 


\section{Research handbook on the economics of antitrust law}

unilateral effects and what the best models are for assessing the likelihood and magnitude of unilateral effects, focusing on mergers in differentiated product markets. In differentiated markets, mergers can create unilateral effects because they allow the merged firm to recapture the profits they would otherwise lose to each other by raising prices, thus increasing their profit-maximizing price. A complementary explanation is that mergers can create unilateral effects by removing the competitive response of an important rival that would otherwise increase firm-specific demand elasticity. Baker and Reitman note that market shares may bear no relationship to such unilateral effects.

Baker and Reitman explore various simple models that can provide a quick preliminary read on likely unilateral effects with relatively light data requirements. They first address the Upward Pricing Pressure model proposed by Carl Shapiro and Joe Farrell, the Chief Economists for the Department of Justice and Federal Trade Commission, which is now included in the 2010 US Merger Guidelines. This model uses the diversion ratio, which is the fraction of customers who would switch from firm 1 to firm 2 in response to a firm 1 price increase. The model calculates that the recaptured profit equals the diversion ratio times the pre-merger profit margin on firm 2's product, and then observes that this recaptured profit has the same impact on firm 1's pricing as an increase in its marginal cost. The reason is that, after the merger, each successful sale of the firm 1 product now has the additional cost of losing that diverted profit on firm 2's product. Thus, such a merger will create upward pricing pressure when the recaptured profit is greater than any cost reduction produced by merger efficiencies. They propose using a standard deduction of some percentage of pre-merger costs. A related model, Compensating Cost Reduction, is similar to Upward Pricing Pressure, but uses the actual expected cost reduction rather than a standard deduction.

Baker and Reitman then address two other simple models. Critical Loss Analysis asks whether, given the demand elasticity for the merged firm's product and its pre-merger profit margin, the merged firm could profitably impose a small but significant nontransitory increase in price (SSNIP). Simple Price Effect models instead project merger price effects using the marketwide elasticity and an assumption that the diversion ratio is proportional to the market share of each brand. As Baker and Reitman observe, this assumption underestimates price effects if the merged products are relatively close substitutes and overestimates them if the merged products are relatively distant.

These simple models can reach decisions with relatively light data requirements that are more accurate than those one would reach using market definition and market concentration presumptions. However, the simple models can reach conclusions that conflict with each other. If the existing profit margins are high, the Upward Pricing Pressure model is more likely to conclude a merger is anticompetitive and Critical Loss Analysis is less likely to do so.

Further, the simple models sometimes deviate from the predictions reached using more complicated merger simulation models, which estimate demand functions for the differentiated products and parameters on costs and oligopoly behavior and then solve the merged firm's price-maximization decision. Assuming the merging firms have the same diversion ratios and profit margins, have constant costs unaltered by the merger, and do not engage in oligopolistic coordination, a Shapiro model shows the percentage price increase equals the diversion ratio times the profit margin divided by (with linear demand) two times the nondiversion ratio or (with constant elasticity) the nondiversion 
ratio minus the profit margin. More complicated models can quantify the degree of uncertainty in price predictions and take into account any merger-specific efficiencies. Merger simulations can also take into account rival reactions and cases where the merging brands are not the closest substitutes for each other.

Baker and Reitman also discuss measurement issues, as well as the possibilities that one might extend these models to take into account various possibilities excluded in standard unilateral effects models. First, they consider the possibility that firms might reposition their products post-merger. Although the Guidelines suggest this would only reduce predicted prices, they note that repositioning by the merged firm could increase price effects. Second, they consider the possibility that firms might price more strategically, noting that while such strategies are difficult to model a priori, they can help address deviations between the simple models and available evidence. Third, they consider bidding markets, noting that the unilateral effects models can be extended to them by assuming firms pick the bid they think most optimal given the need to beat the second best bid, which is sometimes the one offered by the merger partner. Fourth, they consider increasing marginal costs or capacity limits. Although such factors are usually assumed to increase price effects because they reduce the price constraint imposed by nonmerging rivals, they observe these factors can sometimes also reduce the merging firm's incentives to cut output post-merger, making the effects more mixed. Fifth, they consider the extent to which any merger cost-savings are passed on to customers.

Finally, Baker and Reitman observe that the most reliable empirical study of five approved mergers that seemed likely to have presented a close call for US antitrust agencies found that four of the five mergers increased prices by $3-7 \%$. This may suggest the US agencies are being a bit too lax, unless efficiencies take longer to kick in. The increasing access to electronic sales data heralds more such retrospective merger studies in the future, refining our understanding about how best to analyse unilateral effects mergers.

Chapter 3 - Do We Need Market Definition? David Evans' chapter considers the current controversy about the need for market definition. As he notes, under the 2010 US Guidelines, one does not need market definition and the chief economists of the two US antitrust agencies have proposed abandoning it in merger analysis in unilateral effects cases.

Evans provides many arguments for lightening up on the emphasis on market definition. He points out that market definition is one of the few areas not supported by economics. A major problem is that product heterogeneity is the norm, not the exception, so that markets have no sharp boundaries. It thus often makes little sense to talk about 'the' market. Further, he observes that market share is not a reliable indicator of market power because the same market share can indicate much or little market power depending on the market elasticity and rival elasticity of supply. Moreover, he notes that, if we have the elasticity information necessary to do the SSNIP test that is needed to properly define a market, then we have enough information to directly assess the unilateral effects of a merger on price.

Nonetheless, Evans also argues that we should lighten up on the issue generally. In particular, while market definition should be less determinative, he argues that courts should continue to define markets because doing so provides information on competitive constraints. However, courts should not draw hard boundaries or make strong inferences about market power. Instead, as he would use it, market definition would consist more of a narrative about the potential competitive constraints. 


\section{Research handbook on the economics of antitrust law}

This promises to be a hot issue in years to come. Although some cases suggest a need for market definition, many other cases have held that market definition is unnecessary when there is direct evidence of market power or anticompetitive effects. ${ }^{1}$ Moreover, an increasing body of economic literature has indicated that market definition is not only unnecessary, but actually unnecessarily complicates and obscures the analysis, and thus should affirmatively be abandoned. I myself have argued that market definition should generally be abandoned on these grounds, other than in: (a) monopolization or exclusionary conduct cases, where market share may bear on whether a firm is a unitary actor who can exploit buyer collective action problems; or (b) oligopolistic coordination cases, where market definition may indicate whether a firm has few enough rivals to make coordination feasible. ${ }^{2}$ A recent influential article by Professors Farrell and Shapiro argues that market definition should be abandoned just for mergers in differentiated markets. ${ }^{3}$ Finally, a just-published article by Professor Kaplow takes the even more sweeping position that market definition should be abandoned in all antitrust cases. ${ }^{4}$

Evans' theory that market definition might still provide a useful narrative about potential competitive restraints seems to provide the best defense for keeping market definition. The more critical literature effectively responds that elasticities or diversion ratios would give us better and more precise information on competitive constraints, at least in some categories of cases. Still, it can be difficult to carry a matrix of elasticities or diversion ratios around in one's head when thinking about cases, especially in cases that involve the interaction of multiple market levels. For some forms of analytical analysis, it may be useful to exclude firms who, given those elasticities or diversion ratios, impose a weak enough competitive constraint that they are unlikely to change the analysis. Or at least one might want to do so for working purposes, as long as one then tests the ultimate conclusion against the possibility that their more marginal competitive constraint might matter. I would expect this debate to play out in the upcoming years.

Chapter 4 - Modern Analysis of Mergers that Eliminate Potential Competition. The 2010 US Horizontal Merger Guidelines are the first revisions since 1982 to update analysis of mergers involving potential competitors. It is thus particularly timely to address the antitrust analysis of mergers that may raise potential competition issues, which is the topic of John Kwoka's chapter. Whereas older versions classified mergers involving potential competitors as non-horizontal, the 2010 Guidelines call them horizontal.

Kwoka reviews the predicted market results with two firms under various standard

1 FTC v. Indiana Federation of Dentists, 476 U.S. 447, 460 (1986) (direct proof of anticompetitive effects obviates the need to prove market definition or power); Re/Max International v. Realty One, 173 F.3d 995, 1018 (6th Cir. 1999) (collecting cases holding that direct proof of market power obviates need to define markets); P. Areeda, H. Hovenkamp, and J.L. Solow, IIB Antitrust LAW 108 (3rd ed. 2007) (same).

2 E. Elhauge and D. Geradin, Global Antitrust Law and Economics 293-5 (Foundation Press, 2007); E. Elhauge and D. Geradin, Global Antitrust Law and Economics 316-18 (2d ed., Foundation Press, 2011).

3 J. Farrell and C. Shapiro, Antitrust Evaluation of Horizontal Mergers: An Economic Alternative to Market Definition, 10 B.E.J. TheOretical Econ. Iss. 1 (Policies and Perspectives), Article 9 (2010) (in differentiated markets, proving price effects directly is simpler and more accurate than market definition).

4 L. Kaplow, Why (Ever) Define Markets?, 124 Harvard L. Rev. 437 (2010). 
models, assuming a homogeneous product and two identical firms. He shows that the Stackelberg leadership model, coupled with an assumption about the fixed costs of entry, allows an incumbent to set the output that it knows will deter entry. He offers formulas for calculating whether such entry deterrence is profitable, and to measure the increase in inefficiency and consumer harm that results. He then compares these formulas to the monopoly results in order to analyse the effects of a merger with a potential competitor, assuming only one potential entrant exists.

Kwoka finds that in each case a merger that fully compensates the potential competitor for the profits it could have earned from entry is profitable to the incumbent. He also derives formulas for calculating the increase in incumbent profits, inefficiency, and consumer harm that results from merging with a potential competitor. The harm is bigger the more competitive the market would have been without the merger. In the case of Stackelberg leadership, the incumbent would (without the merger) be setting output to deter entry, so the merger eliminates perceived potential competition rather than actual potential competition. He shows that mergers that eliminate perceived potential competition create smaller increases in profits, inefficiency, and consumer harm, consistent with intuition and empirical findings.

Kwoka then notes that, if we relax the assumption that only one potential entrant exists, the other potential entrants may offer enough of a competitive constraint to eliminate any harm from the merger. Also, if we alter assumptions to assume the entrant has higher per-unit costs than the incumbent, eliminating the entrant by merger is less profitable. Finally, if we assume a differentiated market, then one should analyse the merger like a merger between actual competitors, but the analysis is difficult because there is no actual diversion ratio so a projected diversion ratio would have to be estimated.

Kwoka also reports an empirical study finding that an airline merger increased prices by $10 \%$ when it eliminated an existing competitor and by $6 \%$ when it eliminated a potential competitor. Other empirical studies focus on the market effects of each additional potential entrant, a measurement that Kwoka points out reflects the average effect of a potential entrant and thus is likely to underestimate the effect of a merger, which is likely to focus on the most constraining potential entrant. Nonetheless these empirical studies have found statistically significant effects. One study found that each additional competitor in an airline market lowers prices by $4 \%$ and each additional potential competitor reduces prices by $1.4 \%$. Other studies have replicated this conclusion, finding each additional potential entrant reduces prices by $0.25-2 \%$, which is one-third to one-eighth of the effect they find for each additional actual competitor. Some studies find a particularly strong effect if the potential entrant is Southwest, which decreases prices by $12-33 \%$ if it is a potential entrant and by $46 \%$ if it is an actual competitor. Other studies have found that potential entrants significantly constrain prices in markets for railroads and pharmaceuticals. In cable television markets, potential entrants interestingly do not affect prices but instead affect quality, leading incumbents to offer more channels.

Kwoka thus concludes that, although enforcement against potential competition mergers declined from an earlier period, the theoretical and empirical literature indicates that mergers that eliminate potential competitors can have significant anticompetitive effects, even though those effects are less than those of mergers that eliminate existing competitors. He thus applauds the fact that the 2010 US Merger Guidelines include potential competition mergers in their analysis, and recognize that they can have 
significant anticompetitive effects, which he concludes will help elevate the importance of these issues in the future.

\section{PART II AGREEMENTS AND UNILATERAL CONDUCT}

This handbook next moves on to consider various hot topics in the antitrust assessment of agreements and unilateral conduct. Some of these issues are hot because they involve conflicts in law among cases within the United States or between the United States and the EU and other nations. Other issues are hot because they involve issues that have been newly raised by recent Supreme Court decisions and cases.

Chapter 5 - The Recent Economic Literature on Tying, Bundled Discounts, and Loyalty Discounts. Probably the area of antitrust law and economics that is currently most contested is tying, bundled discounts, and loyalty discounts. A slew of recent cases in the United States have adopted diverging standards from each other and from EU cases. ${ }^{5}$ It is thus particularly timely to have Nicholas Economides' chapter unpacking the findings of the economic literature.

Economides begins by clarifying the oft-neglected distinctions between fixed ratio ties, requirements ties, and volume-based ties, the parallel ones between fixed ratio bundled discounts, bundled loyalty discounts, and bundled volume-based discounts, and the distinction between loyalty commitments and conditions. He further observes that any nominal bundled or loyalty 'discount' can really be a penalty if the noncompliant price is set above the but-for price that would prevail without the program.

Economides then rebuts the single monopoly theory for such tying and bundling because they can extract consumer surplus through intra-product price discrimination, intra-consumer price discrimination, or inter-product price discrimination. Further, they can foreclose a substantial share of the tied market in a way that increases tied or tying market power.

Moving on to single-product loyalty discounts, he finds that all-units discounts are more problematic than incremental unit discounts. In particular, he finds that loyalty discounts on all-units can be equivalent to bundling incontestable and contestable demands. He also finds that share-based or individualized discounts are much more problematic than fixed volume-based discounts because the former can extract all consumer surplus and be tailored to exclude rivals.

Economides also rebuts the profit-sacrifice test, finding that no profit sacrifice is necessary to utilize these strategies is an anticompetitive way. The main reason is that buyers have a prisoner's dilemma that makes them willing to accept anticompetitive ties, bundled discounts, or loyalty discounts, as long as they get some trivial individual discount from the noncompliant price, even if the result is that collectively all buyers are harmed. Because no profit sacrifice is required, Economides concludes that the Antitrust Modernization Commission was mistaken to recommend requiring proof that a profit sacrifice was recouped.

Economides also demonstrates various problems with using cost-based tests to assess

5 Elhauge and Geradin, supra note 2, at 625-90 (2d ed). 
bundled or loyalty discounts. First, if these tests use the defendant's costs, they can immunize cases where the conduct successfully made the rival less efficient. Second, these tests allow the exclusion of any less efficient rival, which can harm market efficiency and consumer welfare because such rivals can constrain market power. Third, these tests don't work well in differentiated markets. Fourth, allowing all above-cost bundled or loyalty discounts reduces price transparency. Fifth, the prisoner's dilemma problem means that buyers might accept above-cost bundled or loyalty discounts to avoid penalty pricing.

Economides instead recommends using a structured rule of reason that focuses on whether tying or bundling reduces consumer surplus. Because extracting consumer surplus requires tying market power, but does not require tied market power, a substantial tied foreclosure share, or failure of a price-cost attribution test, he concludes that legal doctrine likewise should require tying market power but not the other factors. However, legal doctrine should consider offsetting efficiencies. He concludes that a similar structured rule of reason should apply to bundled or loyalty discounts if the unbundled or disloyalty price is higher than the but-for price.

Chapter 6-A New Theory of Predatory Pricing. Although the law on predatory pricing has become relatively stable within the United States, the US law on predatory pricing remains in considerable conflict with the EU and among other nations. ${ }^{6}$ In his chapter, Aaron Edlin raises a broad-based attack that undermines the economic premises that underlie current US law's skepticism about predatory pricing and its usage of cost-based and recoupment tests. He proposes a new test, the consumer-betterment standard, to deal with cases of reactive above-cost price cuts that deter or drive out entrants who would offer consumers a better deal than the every-day price the monopolist charges when it does not confront entry.

Edlin begins by showing that predatory pricing is more plausible than had been argued by the Chicago School critique of predatory pricing. Even if one assumes symmetric information and costs, he finds that predation and non-predation are both economic equilibrium, and that which equilibrium holds turns entirely on expectations. He further shows that predation becomes even more likely if instead we have asymmetric information or costs: that is, either if entrants have to infer incumbent costs from incumbent pricing (giving the incumbent incentives to send false signals about its costs with predatory pricing) or if incumbents actually have lower costs (and thus can drive out entrants by cutting prices to levels above incumbent costs but below entrant costs). Finally, he argues that any theoretical ambiguity is resolved by empirical studies showing that predatory pricing does occur often, contrary to the opposite empirical premise asserted by some and relied on by some courts.

Edlin argues that, if one uses a price-cost test, the proper cost standard to use depends on whether the underlying test is a profit-sacrifice test or an equally-efficient-rival test. Under a profit-sacrifice test, he finds that courts should use 'inclusive' measures of costs that include the lost revenue from lowering prices to inframarginal buyers. (The same can be accomplished by using marginal revenue rather than price.) Under an equally-efficientrival test, he finds that courts should use exclusive measures that exclude such costs.

However, Edlin finds that neither test is well-connected to the antitrust goal of

6 Id. at 352-98. 
protecting consumer welfare. Edlin proposes that predatory pricing should instead be governed by a consumer-betterment test, which asks whether a monopolist's 'challenged practice is likely in the circumstances to exclude from the defendant's market a competitor who would provide consumers a better deal than they get from the monopoly'. $\mathrm{He}$ argues that this test does not prohibit limit pricing because there the deal offered by the firm is the limit price, which is better than consumers could get from an entrant. Further, he argues that the consumer-betterment test does not prohibit any permanent price cut in reaction to entry because then the deal offered would be the permanent price rather than the pre-entry price. However, the consumer-betterment test would prohibit a firm from normally pricing high pre-entry, using a temporary price cut to drive out an entrant, and then restoring high prices post-entry, because there the deal offered to consumers by the monopolist before and after the predatory period is worse than the entrant would offer.

This consumer-betterment test is an important new contribution, but one whose precise meaning may need to be fleshed out in future work and which may raise insuperable administrative problems. In particular, the consumer-betterment test requires some methodology for figuring out how to define what counts as the 'deal' offered by the monopolist and entrant in cases where their prices vary over time or with the conduct. For example, Edlin's application of his test suggests by implication that the monopolist's 'deal' does not include pre-entry prices in the event of a permanent price reduction, but does include both the monopolist's pre-entry and post-entry prices in the event of a temporary price increase (but does not include their temporary price reduction). But the underlying methodology for reaching those conclusions about what constitutes the 'deal' is not defined, and it is less clear what the consumer-betterment test would mean in other cases.

To illustrate, suppose a monopolist cut prices to a level above its costs but below an entrant's, and permanently kept them low, and this drove out the entrant. Suppose further that, without the price cut, the entrant would in the long run have become more efficient and lowered prices to below the monopolist's permanently-cut prices. Then, whether the consumer-betterment test allows the conduct turns on whether we deem the entrant's 'deal' to be: (a) the entrant's short-run price, in which case the test allows the conduct; (b) the long-run price the entrant would have offered, in which case the test prohibits the conduct, or (c) the present value of the entrant's short- and long-run prices, in which case the test outcome turns on whether this present value calculation exceeds the monopolist's permanent price. To the extent that the consumer-betterment test condemns such conduct, it differs from the Baumol test, which would allow all permanent price reductions, which is an interesting contribution. But condemning such price cuts would mean that the consumer-betterment test requires a court to project what the entrant's long-run price would have been (which will be hard), or to estimate what the present value of the entrant's stream of projected prices would be (which is even harder), in order to compare them to the monopolist's permanent price cut.

Or consider the following sort of situation. A monopolist prices at 100, an entrant enters at its cost of 76, the monopolist lowers its price to 75 and drives out the entrant. But after the entrant's exit, there is an increase in market quality, costs, or demand, so that, had the entrant remained in the market, the entrant would have increased its price to 90 . Does the consumer-betterment test allow the monopolist to now increase its price to 89 because it is offering a deal that is better than the entrant 'would' have offered at 
the same time? If so, then this is another difference from the Baumol test, which would prohibit price increases after rival exit. Moreover, this difference is even more helpful because it neatly avoids some of the main critiques of Baumol's test, which were that the Baumol test would create inefficient incentives for the monopolist to evade the price cap by worsening quality or would inefficiently freeze pricing despite changes in costs or demand. ${ }^{7}$ However, this interpretation of the consumer-betterment test would also put a lot of administrative burden on courts because it would require courts to adjust any price rule based on counterfactual projections of what the entrant would have charged at each point in time.

All this remains to be fleshed out in future work. For now, Edlin's consumerbetterment test offers a new intriguing possibility that avoids some of the problems of prior approaches. Time may tell whether the administrative problems it raises are so great it is unworkable, or so similar to the administrative problems raised by simply asking whether the conduct worsened consumer welfare that we might as well make that final ultimate question our test.

Chapter 7 - Vertical Price-Fixing After Leegin. Now that the 2007 Leegin decision has overruled the old per se rule against vertical price-fixing, it has raised new issues about how to assess claimed justifications and anticompetitive theories regarding vertical pricefixing. Those new issues will need to be addressed to conduct a rule of reason review, and are tackled in Ben Klein's chapter.

Assessing Procompetitive Justifications for Vertical Price-Fixing. Klein argues that the conventional free-rider justification for vertical price-fixing is too narrow and underdescribed because retailers can always engage in non-price competition that competes away the price floor. Thus, he argues that, even in free-riding scenarios, manufacturers would have to specify the performance they want, and that all vertical price-fixing provides in such cases is a profit margin that makes termination an effective penalty for nonperformance.

Moreover, Klein argues empirically that free-rider problems are not present in many actual cases. Free-riding on services is often inapplicable either because no service is being offered or because the terminated retailers provide the same services as other retailers. Free-riding on quality certification does not apply in many cases either because the product has a well-established brand name, because discounting retailers are terminated even when they have good quality reputations, or because the quality problem could easily be solved by the manufacturer simply refusing to sell the product to low-quality retailers.

Klein argues that the true justification for vertical price-fixing is usually different. It arises from the fact that retailers have discretion about which goods to carry and promote because each retailer has a group of loyal customers who get consumer surplus from going to that store. Thus, he concludes that retailer display or promotion decisions generally have 'significant inter-brand demand effects but little or no inter-retailer demand effects'. In Klein's view, the real reason manufacturers usually use vertical price-fixing is

7 E. Elhauge, Why Above-Cost Price Cuts to Drive Out Entrants are Not Predatory - and the Implications for Defining Costs and Market Power, 112 YaLE L.J. 681, $822-5$ (2003). 
to give retailers a greater return that induces those retailers to exercise their discretion to favor the price-fixing manufacturers in display or promotion.

Klein acknowledges that manufacturers could simply pay directly for promotion or shelf-space, but he points out that this alternative may sometimes be hard to specify and monitor. For example, if may be hard to specify increased salesperson efforts and enthusiasm for a particular brand. Moreover, vertical price-fixing usefully ties the amount of payment to actual success in selling the product, thus aligning incentives and reducing monitoring costs. On this view, vertical price-fixing really solves a problem of contract economics that would be raised by trying to directly contract about promotion or display.

Students of Phillip Areeda may recall that he called this same theory the 'brand pushing' rationale, but that he classified it as anticompetitive rather than procompetitive. He argued that giving retailers greater returns on some brands in order to get them to push sales of it over others would distort retailer's advice to consumers and thus harm consumer welfare. ${ }^{8}$ It would give retailers incentives to recommend the higher-profit brands even though their prices were higher and quality worse than other brands, either directly through salesperson recommendations or implicitly through promotions or display location. Moreover, Areeda reasoned that allowing vertical price-fixing would give each manufacturer incentives to adopt vertical price-fixing to prevent other brands from being pushed over its brand, with the result being a prisoner's dilemma where every manufacturer would use vertical price-fixing to get brand-pushing, but in the end no manufacturer would gain any relative advantage and all would suffer from excessive retail margins and unresponsive retail prices. ${ }^{9}$ He anticipated the Klein type of argument that using vertical price-fixing to buy brand pushing reflects desirable competition for promotional services, but argued that bidding for promotional services is not procompetitive when the promotional service consists of retailer efforts to mislead consumers. ${ }^{10}$

So one basic issue that arises in the wake of Leegin is how we should think of this brand-pushing rationale for vertical price-fixing. Should we view it, as Klein does, as inherently procompetitive competition for retail distribution? Or should we view it, as Areeda argued, as an anticompetitive and inefficient effort to distort retailer advice and harm consumer welfare? I would expect this issue to be hotly contested in years to come, but the early legal returns seem to favor the Areeda approach. In Leegin itself, the Supreme Court held that one of the 'the potential anticompetitive consequences of vertical price restraints' was that '[a] manufacturer with market power . . . might use resale price maintenance to give retailers an incentive not to sell the products of smaller rivals or new entrants'. ${ }^{11}$ Thus, the Leegin Court treated as anticompetitive precisely what Klein characterizes as the principal procompetitive justification for vertical price-fixing.

Another issue arises from the rationale's premise that inter-retailer demand effects are low because that premise also suggests that retailers should not care what prices other retailers are charging for the same brand. The premise thus leaves it unclear why retailers

See VIII P. Areeda, Antitrust Law para. 1601(6) at 15, para. 1614 at 194-8 (1989).

Id. at $15,197-8$.

$10 I d$. at 197. In subsequent volumes of the antitrust law treatise, Professor Hovenkamp also adheres to the Areeda conclusions summarized in this paragraph. See VIII ArEEDA AND Hovenkamp, ANTITRust LaW para. 1601 at 16-17, para. 1614 at 178-81 (3rd ed. 2010).

11 Leegin Creative Leather Products v. PSKS, Inc., 551 U.S. 877, 894 (2007) (emphasis added). 
need vertical price-fixing at all. Each retailer could itself just determine the retail price for each brand that gives the retailer enough of a margin to cover the promotion and display the retailer chose for that brand, because the lack of inter-retailer demand effects makes the prices at other retailers irrelevant.

Moreover, given the premise of low inter-retailer demand effects, it is not clear why a manufacturer that wanted to encourage pushing of its brand could not do so without vertical price-fixing by simply lowering its wholesale price. ${ }^{12}$ Cutting its wholesale price would give retailers a higher profit margin on its brand than on other competing brands at any given retail market price for the product. Cutting wholesale prices thus seems a less restrictive alternative for advancing brand-pushing. To be sure, this alternative would also encourage a prisoner's dilemma where every manufacturer lowered its wholesale price to get brand-pushing, and thus none got it in the end. But, as shown above, using vertical price-fixing to incentivize brand-pushing also raises a prisoner's dilemma. Moreover, here the prisoner's dilemma is the virtuous one that underlies all competitive pricing, resulting in competitive low wholesale and retail prices, as well as in retailers whose advice to consumers is undistorted and who can vary retail prices with retailer cost variations over time and between retailers.

Finally, it should be noted that the Klein justification for vertical price-fixing is only potentially applicable to multi-brand dealers. If he is right that free-riding truly does not explain much vertical price-fixing, then that may leave little justification for the use of vertical price-fixing with single-brand dealers.

Assessing Anticompetitive Theories for Vertical Price-Fixing. Klein then assesses possible anticompetitive theories for vertical price-fixing after Leegin. He begins by considering manufacturer-motivated theories. One possible theory is that vertical price-fixing might facilitate a manufacturer cartel. It can do so either by decreasing manufacturer incentives to cut wholesale prices or by making it easier to detect such cuts. Klein acknowledges this possibility, and argues that proving it should require proving widespread use by rival manufacturers and sufficient market concentration. He also argues that the facilitating effects may be weaker than commonly supposed because each manufacturer still has incentives to cut wholesale prices to get its brand pushed. But his last point also raises the issue, noted above, about whether cutting wholesale prices is a less restrictive alternative for accomplishing what he finds to be the main rationale for vertical price-fixing.

A second manufacturer-motivated anticompetitive theory is that vertical price-fixing might allow a manufacturer to maintain its market power by giving retailers incentives not to carry smaller rivals or entrants. Here Klein critiques the Leegin Court's conclusion that it is anticompetitive to give retailers incentives to favor the powerful manufacturer over rival brands, arguing that doing so just reflects desirable competition. This argument

12 If instead inter-retailer demand effects are high, then intra-brand retail competition will be high, and lowering the wholesale price will predictably lower retail prices at all retailers and bring retailer profit margins back to competitive levels, eliminating the incentive to push. See VIII AREEDA, ANTITRUST LAw para.1614 at 195(1989); VIII AREEDA AND HovenKAMP, ANTITRUST LAW para.1614 at 178-9 (3rd ed. 2010). The same would be true of manufacturer efforts to achieve the same sort of brand-pushing by simply paying dealers a bonus for increased sales, which is equivalent to lowering the wholesale price. Thus, if inter-retailer demand effects are high, then vertical price-fixing does seem necessary to encourage brand-pushing, raising the issue of whether such brand-pushing is desirable. 
raises the basic question, noted above, about whether to classify this effect as procompetitive under the Klein theory or anticompetitive under the Leegin-Areeda theory. Because Klein rejects the latter, he would require proof not only of manufacturer market power, but also of some actual or de facto exclusivity requirement. However, if the latter existed, we would really have a case of exclusive dealing, which is addressed under another antitrust doctrine. Thus, Klein effectively is arguing that mere vertical price-fixing imposed by a powerful manufacturer should be per se legal, unless one can prove it facilitates a manufacturer cartel.

Klein moves on to consider retailer-motivated anticompetitive theories. On both of these theories, the Leegin Court suggested it was relevant whether retailers were the source or initiator of the vertical price-fixing. However, Klein argues that this factor may not have economic significance because both manufacturers and retailers can benefit from vertical price-fixing, and thus either might suggest it. Although Klein emphasizes that either might initiate for procompetitive reasons, it is also true that either might initiate for anticompetitive reasons at either level. ${ }^{13}$

The first retailer-motivated theory that Klein considers is that vertical price-fixing might facilitate a retailer cartel. He argues that this theory requires evidence of a large share of retailers jointly communicating with the manufacturer. He further argues that this theory is strengthened by proof that the manufacturer market is unconcentrated. This latter point indicates that proving manufacturer market power should thus not be a requirement for all vertical price-fixing cases.

The second retailer-motivated anticompetitive theory is that a powerful retailer might use vertical price-fixing to impede competition from retailer rivals who are more efficient or innovative. Klein argues that this theory should require proof that a retailer has market power and that vertical price-fixing covers a significant share of the product market.

Finally, based on his premise that vertical price-fixing is generally procompetitive, Klein argues that the plaintiff should have to show anticompetitive effects before a defendant has to show procompetitive justification. However, if Klein is right that vertical price-fixing is usually motivated by encouraging brand-pushing rather than by curbing free-riding, and one instead adopts the Areeda-Leegin position that brandpushing is anticompetitive, this would suggest the opposite conclusion: that vertical price-fixing is usually anticompetitive and that the defendant should have to prove a procompetitive justification first.

Klein also argues that proving increased prices should not suffice to show an anticompetitive effect because such a price increase is consistent with his procompetitive theory. Once again, this conclusion depends on his categorization of the brand-pushing rationale. He also argues that under all four anticompetitive theories, a plaintiff should have to show that the vertical price-fixing led to decreased market output and that the retailer-

13 E. Elhauge, Harvard, Not Chicago, 3 Competition Policy InT'L 59, 60-68 (Autumn 2007) ('Even if a dealer initiated the restraint, dealers have incentives to offer terms that they think manufacturers will find efficient and profitable. Further, even if a manufacturer initiated the restraint, any individual manufacturer has incentives to get dealers to carry its products by offering terms it knows a powerful dealer or dealer cartel will find profitable, even if those profits come at the expense of consumer welfare. Moreover, the Court itself acknowledged that manufacturers could have their own anticompetitive incentives for imposing vertical minimum price-fixing'). 
motivated theories should require proof of a decrease in the individual manufacturer's sales.

Chapter 8. Proving Horizontal Agreements After Twombly. The 2007 Supreme Court decision in Twombly creates new - but somewhat obscure - standards for alleging and proving horizontal agreements. In their chapter, Alvin Klevorick and Issa KohlerHausmann offer a descriptive theory that uses the notation of Bayesian probability to helpfully formalize the relevant standards. They argue that the case law shows the relevant standards differ on a motion to dismiss and on summary judgment.

On a motion to dismiss, they argue that, if the plaintiff does not allege direct evidence of a conspiracy, the Twombly plausibility standard requires that the plaintiff allege parallel conduct and at least one 'plus factor'. They use Bayesian analysis to define a 'plus factor' as a fact that makes the probability of a conspiracy (given the parallel conduct and that fact) higher than the probability of a conspiracy would be with just the parallel conduct and without that fact.

On summary judgment, they argue that, if the plaintiff lacks direct evidence of a horizontal conspiracy, the 'tends to exclude' standard requires that the plaintiff instead satisfy the following Bayesian standard. The plaintiff must show that the probability of a conspiracy (given the parallel conduct and all the plus factor evidence in combination) is higher than the probability of independent action (given the same evidence).

Chapter 9. Modern Analysis of Monopsony Power. Roger Blair and Jessica Haynes's chapter focuses on the monopsony issues that have been increasingly raised by the Supreme Court's 2007 Weyerhaeuser decision and by recent allegations of buyer cartels among Major League Baseball owners, the NCAA, antique dealers, hospitals, and timber bidders. They model monopsony problems, and show how to adapt the Lerner Index and standard dominant firm and oligopoly models to the monopsony context.

They further prove that the reduction in input prices reduces the monopsonist's output and thus leads to increased downstream prices, contrary to the lay intuition that reducing input prices should reduce downstream prices. Finally, they apply their analysis to cases, including Weyerhaeuser.

\section{PART III ANTITRUST ENFORCEMENT}

The handbook ends by considering current issues of antitrust enforcement. One important choice is between public and private enforcement. This is a live current topic, as other nations like the EU member states consider adding significant private enforcement to their public enforcement regimes, and as US decisions curb private enforcement in favor of public enforcement. Another issue is the timing of enforcement, an issue that is raised not only by the increasing emphasis on retrospective private enforcement in many nations, but also by US agency efforts to attack some mergers retrospectively rather than prospectively. An even more fundamental choice is between using consumer welfare and total welfare standards to guide enforcement. This issue has become increasingly disputed in the economic literature, with the most interesting development being the development of literature indicating that using a consumer welfare standard may actually advance total welfare objectives better than a total welfare standard would.

Another major current topic concerns problems raised by the recent increase in 
multi-nation antitrust enforcement for any given merger or conduct that has resulted from the fact that markets are increasingly international and more nations have begun to adopt and seriously enforce antitrust laws. Other issues are raised by recent court decisions on the intersections between antitrust and patent law, and between antitrust and other regulatory statutes. Finally, recent economic literature has led to interesting insights about how best to measure damages. This final part of the handbook considers all these topics.

Chapter 10. New Developments in the Economic Analysis of Optimal Antitrust Enforcement. In his chapter, Abraham Wickelgren summarizes recent scholarship on optimal antitrust enforcement on a host of issues.

Public v. Private Enforcement. As Wickelgren notes, the EU has recently been considering procedural changes to increase its private enforcement of antitrust laws, so it is particularly timely to consider the literature on the optimal mix of public versus private enforcement. Private enforcement may lead to underenforcement or overenforcement because the expected damages may be less than or greater than the negative externality from an antitrust violation. Private enforcement also will not consider the deterrent effect (leading to underenforcement) or the social loss from defendant litigation costs (leading to overenforcement).

Compared to public enforcement, private enforcement has the advantage of being more likely to detect violations but the disadvantage that it may be used anticompetitively to disadvantage rivals because of the prospect of erroneous decisions. Wickelgren notes that a recent economic model finds that adding private enforcement to public enforcement increases welfare as long as courts are sufficiently accurate, but that if courts are less accurate it is optimal to rely solely on public enforcement. Relying solely on public enforcement is thus more likely to be optimal in nations that have relatively inaccurate judicial systems. Further, as a nation's judicial system becomes more accurate in assessing antitrust cases, the nation is likely to find it more optimal to increase private enforcement.

In deciding which cases to publicly enforce, Wickelgren focuses on two branches of literature that suggest shortfalls in private enforcement that might make particularly good cases for public enforcement. One paper found that, although competitor suits encourage entry that lowers prices, competitor suits can also soften post-entry competition because they give the incumbent incentives to increase prices to reduce its lost profit damages. Another paper found that, if consumers mentally discount cartel prices by their anticipated antitrust damages when deciding how much to consume and know the firms' costs, then consumer suits will deter cartels only if the damage multiple times the detection odds exceed 1. However, even if this figure is less than 1, consumer suits can deter cartels if consumers do not know the firms' costs and thus cannot be sure whether high prices reflect cartel pricing or costs. Moreover, it is unclear that real consumers mentally discount prices by anticipated antitrust damages or know the detection odds necessary to do so.

Enforcement Timing. Wickelgren also analyses the choice of whether to engage in ex ante enforcement (such as prospectively blocking mergers) or ex post enforcement (retrospectively challenging anticompetitive mergers or conduct). He finds that ex ante enforcement is more optimal the lower the prospective uncertainty about the effects and the higher the costs of reversing those effects (such as when it requires undoing a merger). Ex post review also has other mixed effects in that it can: (1) undermine a regulator's ability to commit to optimal policy, (2) induce more beneficial post-merger conduct, or (3) induce inefficient efforts to make it costly to undo a merger. 
Consumer Welfare v. Total Welfare. Wickelgren also addresses the much-debated issue of whether consumer welfare or total welfare should be the standard agencies and courts use. He first points to reasons why total welfare should be the ultimate objective, but then explains why using a total welfare standard may not actually be best to achieve that objective.

On the reasons for making total welfare the ultimate objective, Wickelgren points out that consumer welfare has an imperfect fit with distributional concerns because antitrust victims are not always poorer than violator shareholders. Further, if one tried to limit the consumer welfare standard to cases where antitrust victims were poorer than violator shareholders, that would add legal expense and uncertainty and lead to the same work disincentives as the tax system, which could achieve redistribution better. However, Wickelgren does not respond to the point that, despite the imperfect fit, if antitrust victims are usually poorer than violator shareholders, then a consumer welfare standard applied across the board could further redistribution without work disincentives. ${ }^{14}$ This may be more optimal than using the tax system to achieve more precise redistribution with greater work disincentives.

More interestingly, even on his assumption that total welfare should be the ultimate objective, Wickelgren finds that the economic literature indicates that this objective may sometimes be advanced better by using a consumer welfare standard. The reasons turn out to be numerous.

The first reason is that a total welfare standard will cause firms to choose the most profitable action among the actions that increase total welfare, which can differ from the profitable action that increases total welfare the most. A consumer welfare standard can drive firms to instead choose the action that increases total welfare the most. Indeed, the literature finds that, for uniform distributions, if the number of possible actions is four, then a pure consumer welfare standard is the one that maximizes total welfare. If the number of possible actions is less than four, the maximizing standard is somewhere between total and consumer welfare. If the number of possible actions is more than four, the maximizing standard is actually stricter than consumer welfare.

The second reason is that, if firms have private information about their efficiencies, then there is an enforcement probability that leads to firms proposing mergers only when they increase total welfare, but using such an enforcement probability would make all proposed mergers increase total welfare. Thus, an agency that used a total welfare standard would approve all mergers, thus deviating from the optimal enforcement probability. This analysis indicates that deviations from total welfare toward consumer welfare are likely to be optimal, though it does not necessarily support a pure consumer welfare standard.

Third, if monopolists dissipate their monopoly profits in efforts to obtain market power, then those monopoly profits wash out ex ante, and thus a consumer welfare standard may better maximize ex ante total welfare. An ex post total welfare standard would approve actions that increase monopoly profits by more than they harm consumer welfare, but if the increased monopoly profits are totally dissipated ex ante, such actions

14 See E. Elhauge, The Failed Resurrection of the Single Monopoly Profit Theory, 6(1) COMPETITION Policy InT'L 155, 168 (Spring 2010). 
would harm ex ante total welfare..$^{15}$ The greater the share of monopoly profits that are dissipated ex ante, the more likely it is that a consumer welfare standard does a better job of advancing ex ante total welfare than an ex post total welfare standard would.

A fourth point, which Wickelgren does not address, is that generally firms should be able to restructure any action that increases total welfare in a way that does not harm consumer welfare, perhaps by using their efficiency gains to fund consumer welfare trusts. ${ }^{16}$ Given this, a consumer welfare standard usually seems unlikely to block action that increases total welfare, but instead would only induce the restructuring necessary to make sure that consumers benefit as well. This point also seems related to the first point above, because if manufacturers have to structure their actions to preserve consumer welfare, they might as well choose the action choice that maximizes total welfare because that will generally also maximize their profits given the lack of harm to consumer welfare.

Finally, a fifth point, also not addressed by Wickelgren, is that a consumer welfare standard makes it easier to coordinate international enforcement. ${ }^{17}$ The reason is that concurrent international antitrust enforcement effectively allocates decisive power to the most aggressive enforcer, which is likely to result in decisive power being exercised by the importing nations that have the most incentive to be aggresive. Such importing nations have incentives to apply a consumer welfare standard correctly, but would have incentives to underweigh producer benefits if they were applying a total welfare standard.

International Enforcement. Although he does not consider its connection to the welfare standard, Wickelgren does briefly discuss international enforcement. He observes that, given concurrent international enforcement, a decision by the United States or the EU matters only if the other has approved the merger. He finds that this can lead to problems similar to the winner's curse in auctions, unless each takes into account the signals created by the decisions of others. The next chapter addresses international enforcement at greater length.

Chapter 11. Dealing With the Contemporary Increase in Multi-Nation Antitrust Enforcement. Anu Bradford's chapter focuses on the increasing importance of antitrust enforcement by multiple nations, given the proliferation of antitrust laws in more nations and the increasingly international nature of markets and thus of mergers or antitrust claims. She notes that without any overarching international antitrust regime, this multi-nation enforcement regime leads to three problems.

First, multi-nation enforcement can increase transaction costs and uncertainty for firms. For example, recent surveys have found that the typical international merger requires filing in six agencies and takes seven months and US \$5 million to complete, even if the merger filing results in no serious investigation, with each additional jurisdiction increasing the delay and cost. Although the cost is only $0.11 \%$ of the costs of the average merger deal, she argues this amounts to a tax on international mergers that is regressive because it disproportionately burdens small mergers. Further, decisions by multiple regulators can conflict with each other, increasing uncertainty.

15 See Elhauge, supra note 14, at 169-72; E. Elhauge, Tying, Bundled Discounts, and the Death of the Single Monopoly Profit Theory, 123 Harvard L. REV. 397, 439-42 (2009).

16 See Elhauge, supra note 14, at 168-9; Elhauge, supra note 15, at 438.

17 Elhauge, supra note 15, at 438. 
However, she notes this concern may be overblown because very few mergers have actually produced a conflict and firms can always conform their behavior to the more aggressive regime.

Second, she argues that multi-nation enforcement can lead to antitrust protectionism. One possibility is that states might be influenced by their trade flows, overenforcing antitrust law if they are net importers and underenforcing antitrust law if they are net exporters. Bradford observes that this theory must assume nations are in a prisoner's dilemma that causes them to choose suboptimal enforcement and cannot reach binding agreements to prevent it. Moreover, she notes that trade flows are a relatively small percentage of any nation's GDP and fluctuate over time. Finally, she observes that Elhauge and Geradin have pointed out that net-importing nations actually have optimal enforcement incentives if they adopt a consumer welfare standard and that underenforcement by net-exporting nations is irrelevant given the enforcement by netimporting nations.

Antitrust protectionism might also arise from the fact that most nations exempt export cartels, thus allowing anticompetitive conduct that harms consumers outside their borders. However, just as Elhauge and Geradin's point means that a general underenforcement by net-exporting nations does not matter given enforcement by net-importing nations, so too it means that a specific underenforcement by a nation that exports a particular product does not matter given enforcement by the nations that import that product. Bradford stresses that this logic assumes the importing nations have the resources and evidentiary access to enforce their antitrust laws, which may not always be true.

Antitrust enforcement might also arise if states underenforce antitrust laws against domestic firms, while overenforcing them against foreign firms. However, she notes that the actual evidence is that the EU is half as likely to block a merger involving a US firm. On the other hand, early concerns have been raised about whether China's enforcement of its brand new antitrust statute is favoring domestic firms. This is an issue that can be expected to become increasingly controversial in years to come.

Third, following another argument from Elhauge and Geradin, Bradford observes that multi-nation enforcement can lead to global overenforcement because the most aggressive enforcer always prevails given concurrent antitrust jurisdiction. Thus, even if nations are equally likely to overenforce as underenforce, the overenforcing result will prevail. Further, it means that nations that favor less stringent antitrust enforcement (such as the United States) effectively cede de facto international authority to nations that favor more stringent enforcement (such as the EU).

Because of concurrent jurisdiction, international antitrust enforcement will not have the 'race to the top' or 'race to the bottom' character that international regimes do with choice of law rules that put one jurisdiction in charge of each firm. However, Bradford observes that this tendency to overenforcement may helpfully compensate for underenforcement by antitrust jurisdictions that lack enforcement capacity or prefer to free ride on the enforcement efforts of others.

Despite the above three problems, no overarching international regime has arisen. Bradford argues that one important reason for this is a substantive disagreement about what the optimal antitrust rules are. Thus, Bradford argues that the underlying gametheoretic problem is not a prisoner's dilemma (where both nations would favor the same agreement) but a coordination game, where the nations differ on which international 
agreement is optimal, even though they may both be better off with some agreement than with nonagreement. This may be the case because different sorts of antitrust laws are favored by the United States and EU, by developed and developing nations, or by net-importing and net-exporting nations.

Another reason for the nonadoption of international antitrust law is the perception that the net benefits of an international agreement would be small relative to the costs. Those net benefits might seem low because the actual transaction costs are a small percentage of deal costs, actual international conflict is rare, underenforcement by exporting nations is adequately addressed by enforcement by importing nations, and the general tendency for errors to cause overenforcement in a multiple-enforcer regime is offset by the underenforcement tendency caused by free-riding or weak antitrust regimes. The costs of international agreement may be relatively high because they include not only the costs of deviating from a nation's optimal antitrust regime, but also the negotiation costs of reaching an international agreement and the agency costs of having international enforcers who are difficult for individual nations to monitor.

Chapter 12. Current Issues in the Intersection of Antitrust and Regulation. Howard Shelanski's chapter addresses the intersection between antitrust and regulation. He argues that the issue has changed with the 2004 and 2007 Supreme Court decisions in Trinko and Credit Suisse, which weakened the historical reluctance of courts to hold that federal regulation triggered antitrust immunity. Before those decisions, the case law presumed that antitrust law could operate in parallel with regulatory laws unless a 'plain repugnancy' between them could be established. Trinko, he notes, might be read to make it harder to bring any novel antitrust claims against firms subject to regulatory oversight even when the regulatory law has an antitrust saving clause. Credit Suisse seemed to extend the concept of 'repugnancy' to include cases where judicial error might lead to conflict, although a narrow reading of the case might limit Credit Suisse to core areas regulated by securities law.

Shelanski notes that this doctrine is premised on the questionable empirical premise that false positives leading to antitrust overenforcement are more costly than false negatives that lead to regulatory underenforcement. On underdeterrence, he observes that regulatory agencies may fail to actively exercise their authority or erroneously fail to condemn conduct. On overdeterrence, he observes that the Antitrust Modernization Commission found that, although overdeterrence was a valid theoretical concern, '[n]o actual cases or evidence of systematic overdeterrence were presented to the Commission'. Further, many other Supreme Court cases have narrowed antitrust in a way that reduces overdeterrence, and empirical studies show that the lion's share of essential facility claims have been held not to raise a triable issue of fact. Moreover, the concerns about overdeterrence from self-interested private litigation do not apply to public litigation by antitrust agencies, and yet the regulatory exemption doctrines preclude both.

Shelanski suggests various ways to mitigate these problems. First, courts could read Trinko and Credit Suisse narrowly. Second, Congress or the Supreme Court could adopt clearer standards for antitrust immunity, which the lower courts could apply in a caseby-case way. Third, either could exempt the antitrust agencies from the Trinko and Credit Suisse rulings. Fourth, Congress could give regulatory agencies authority to make caseby-case antitrust-like rulings even without rulemaking, to make up for the displacement of such ex post case-specific review by antitrust courts. 
Chapter 13. Current Issues in the Patent-Antitrust Intersection. Chris Sprigman's chapter addresses the intersection of patent and antitrust law. He argues that while earlier antitrust law was hostile to patents and aggressive exercises of patent rights, more recent antitrust case law has moved away from this hostility. He argues that there is a fundamental conflict between antitrust and intellectual property law because, while both seek to foster innovation and consumer welfare, antitrust seeks to do so by fostering competition, whereas intellectual property law does so by preventing competition in certain areas. However, he also notes that the right to exclude provided by intellectual property law does not differ from the right to exclude provided under other forms of property law, so that there is no real reason to treat exercises of the different property rights differently under antitrust law.

In the Supreme Court's Kodak decision, Sprigman notes that foreclosing rival service organizations may have been used to extend market power in parts beyond the length of the patents. He argues that while the 2006 Illinois Tool Works decision was right that most patents do not confer market power, the court should nonetheless have inferred market power from the ability to impose a burdensome requirements tie involving complementary products, arguing that such a burden could have been inferred not only from licensee objections but also from the fact that the tied product cost 2.5-4 times as much as identical alternatives. He argues that such ties produce price discrimination that reliably reduces consumer welfare but yield no reliable increase in total welfare. Sprigman also reviews antitrust analysis of patent licenses, patent pools, patents obtained by fraud, and the recent hot topic of reverse payments in settlements of pharmaceutical patent infringement cases.

Chapter 14. Modern Methods for Measuring Antitrust Damages. In the final chapter, Professor Rubinfeld provides an analysis of how to calculate antitrust damages. This is again quite timely given the growth of private antitrust enforcement outside of the United States, and reflects developments in modern economic analysis of antitrust damages.

Rubinfeld begins by analysing the measurement of overcharge damages, which he says generally use either the yardstick or benchmark approach. Under the yardstick approach, prices or margins in the violation market are compared to prices or margins in related nonviolation markets. The latter could be the same product in different but similar geographic markets, or it could be different but similar products in the same geographic market. Under the benchmark approach, prices during the violation period are compared to prices in the same market before or after the violation period.

Under either approach, one can use regression analysis to control for any differences in costs, demand, or degree of competition either between the violation market and yardstick market or between the violation period and benchmark period. Under the benchmark approach, one can also use either (1) a forecasting method that uses only data from the nonviolation period to predict but-for prices during the violation period, or (2) a dummy variable approach, which uses data from all periods but uses a dummy variable to distinguish periods when the violation occurred. He observes that one should also take into account that the violation may itself affect the correlation between the covariates and prices, and shows how to account for this in the regression.

How does one choose between these approaches when they conflict? Rubinfeld notes that if quantity is not correlated with the omitted variables, then the two approaches 
generate consistent predictions. However, the forecasting estimates vary more than the dummy variable estimates. On the other hand, a forecasting approach is less likely to be corrupted by the anticompetitive behavior during the violation period. Particularly worrisome is that if one uses a sufficient number of irrelevant variables, one can always use an in-sample model that produces a damage estimate of zero. Yet the disadvantage of the forecasting approach is that it may work less well if the relationship between prices and covariates is changing rapidly over time.

Rubinfeld notes that overcharge damages are underdeterring because they do not take into account the deadweight loss; that is, the fact that higher prices induce buyers to make fewer purchases. He notes that this underdeterrence may be offset by trebling damages. On the other hand, others have calculated that this failure to account for deadweight loss, coupled with the inability to recover for umbrella effects or pre-judgment interest, reduces treble damages to single damages on average. ${ }^{18}$ Given that one needs some damage multiple to offset the odds of nondetection, this suggests underdeterrence.

Rubinfeld then turns to measuring lost profits damages. One method is to use the yardstick or benchmark method to estimate but-for prices, and then add estimates of but-for costs and a demand model to estimate but-for quantities. Another method is the market-share approach, which compares the profits the plaintiff in the actual and but-for worlds. The difficulties are that it may be difficult to control for other factors that affect market share or to apply the approach to new entrants.

Rubinfeld turns next to indirect purchaser cases, which are prohibited under current federal antitrust law but allowed under most state antitrust laws. He notes that indirect purchaser damages raise many complications, but that one should calculate them by using a reduced-form method to measure the pass-through rate. Under this method, one uses a regression to estimate the extent to which an increase in an intermediate firm's upstream costs leads to increases in its downstream prices. He observes that if the federal damages rule is optimal (on which he notes the evidence is weak), then adding indirect damages produces overdeterrence.

The Antitrust Modernization Commission suggested solving this duplicative damages problem by allowing indirect purchaser suits under federal law, but also allowing a passthrough defense to reduce damages from the direct purchaser. Rubineld notes a recent article finds that, in complex supply chains, direct purchaser overcharges underestimate the total antitrust harm. Another interesting paper finds that, if the direct purchaser is a monopolist, its deadweight loss from an upstream cartel equals the amount of the overcharge that it would pass through. Thus, an overcharge measure provides a good measure of the harm suffered by such a direct purchaser, but allowing the direct purchaser to recover the overcharge and the indirect purchasers to recover the pass-through would better approximate the total antitrust harm in the direct market (though understate the total harm given downstream effects).

Finally, Rubinfeld addresses the practice of awarding discount coupons rather than damages. He notes that one problem with these remedies is that the actual redemption rate tends to be low. Another problem is that, to the extent they are redeemed, they will lead to overconsumption by artificially lowering the price, and that the deadweight loss

18 See Robert H. Lande, Five Myths About Antitrust Damages, 40 U.S.F.L. Rev. 651 (2006). 
from this can be comparable to that created by the overcharge itself. However, giving plaintiffs a choice between coupons and cash damages that are lower than the coupon amount can lead to superior results because it induces plaintiffs who suffer more harm to select coupons and other plaintiffs to select cash. 
Einer Elhauge - 9780857938091 